\title{
Non-dimensional method of capacity limit states for the assessment of the safety level in the structures of large panel buildings.
}

\author{
Piotr BIERNOWSKI ${ }^{* 1}$ and Adam BARYŁKA ${ }^{2}$ \\ ${ }^{1}$ University of Warmia and Mazury in Olsztyn, Faculty of Technical Sciences \\ ${ }^{2}$ Center for Construction Expertise - IBOA Institute, Warsaw, Poland
}

\begin{abstract}
In the article deals with the European safety issues of large-panel buildings from the point of view of exceeding the ULS. The proprietary assessment method was proposed under the name: Dimensional Limit States Method, which is dedicated to the assessment of the safety level in the structures of large-panel buildings. The work was based on many years of computer research conducted by the author. In the paper uses the proprietary construction model of the Wk-70 system building, presents the results for vertical reinforcement inserts.
\end{abstract}

Keywords: construction safety, large-panel construction, structure modeling, scratching, ULS

\section{Introduction}

The issues related to buildings erected in industrialized structural systems, implemented under the banner of large panel boards [8-10,12] at the moment, raise a number of interests and concerns [13-16]. The paper presents an original method of describing the safety condition of the construction of large-panel buildings. The Dimensionless Ultimate Limit States Method, which was developed on the basis of computer studies of stress redistribution in large-panel buildings [3-7], may be a new look at the safety of the construction of large-panel buildings.

In order to describe the method and present the results, a model of the construction of the Wk-70 large-panel building was developed, Fig.1. The prefabricated load-bearing plate structure was modeled as a shell structure - Fig.

2. Thus, more information was obtained about the spatial work of the building structure $[1,2]$.

\section{The results of normal stresses in the upper and lower layer of the FEM coating}

Figures 3 and 4 show the stress maps on the basis of which the degree of reinforcement was determined, point 3 of this study.

\section{Dimensionless Ultimate Limit States Method and results of computer analysis}

The description of the safety level of the construction of large-panel buildings, proposed in the work, was based on the data contained in the literature [10,12], concerning the required minimum cross-sectional area of the concrete cross-section As, min, sgn $\left[\mathrm{mm}^{2}, \mathrm{~cm}^{2}\right]$ of prefabricated load-bearing walls. The minimum concrete cross-sectional area for a structural, precast concrete load-bearing wall is $0.6 \mathrm{~cm}^{2} / \mathrm{mb}$ for each direction - vertical and horizontal. It should be emphasized that the large-slab buildings with $\mathrm{V}$ above-ground storeys were erected using concrete walls. The reinforcement in this case was of an assembly and anti-shrinkage character of concrete, due to the load-bearing

*corresponding author: E-mail address: (piotr.bieranowski@uwm.edu.pl)

https://doi.org/10.37105/iboa.104

Received 15 February 2017

Available online 16 September 2020

Available online 31 March 2021

ISSN 2450-1859, eISSN 2450-8721

Published by Centrum Rzeczoznawstwa Budowlanego 


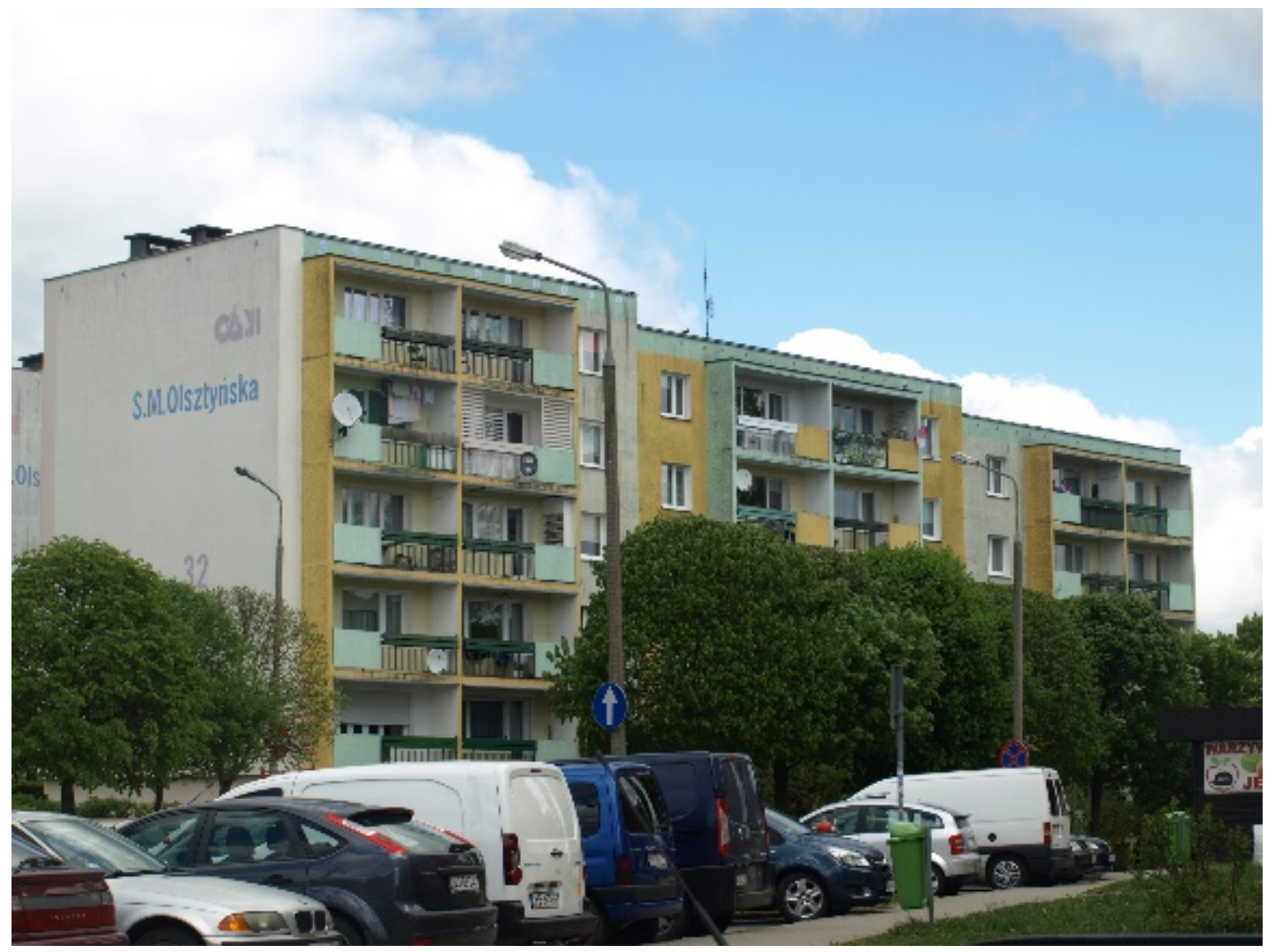

Figure 1. A residential building constructed in the Wk-70 large-panel system
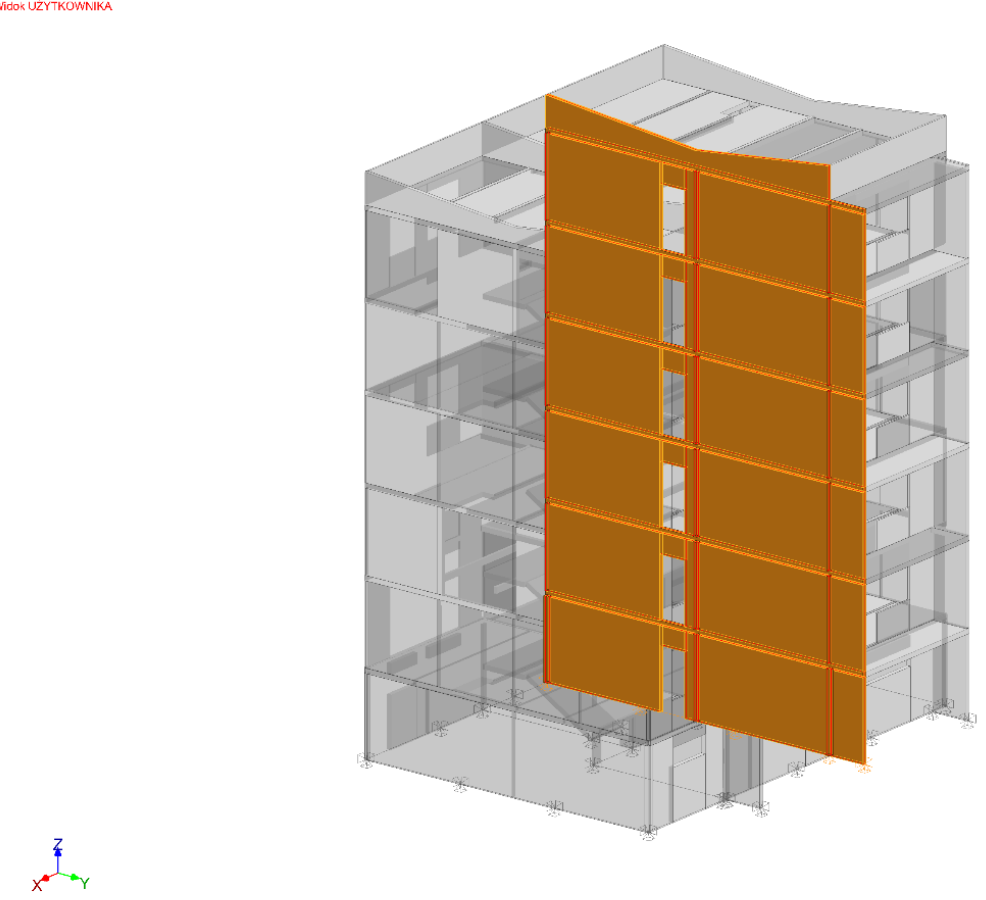

Figure 2. Load-bearing wind diaphragm - layout in the building structure of the Wk-70 system

capacity it was not required. Reinforcement of concrete cross-sections occurred in various systems, e.g. perimeter meshes, single, double-sided, and mixed configurations. 

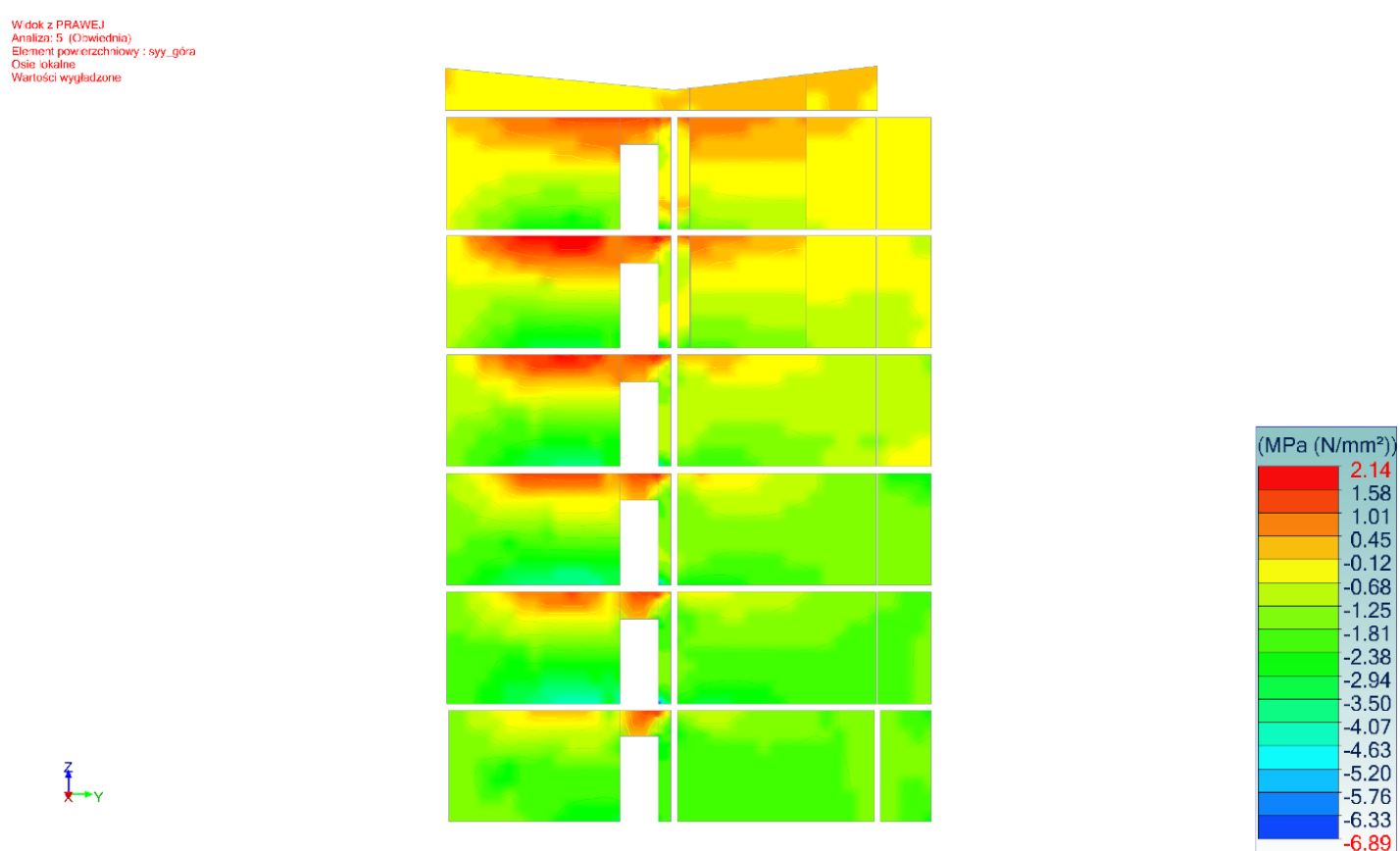

Figure 3. Map of stresses $\sigma_{y y}$ (vertical) in the upper layer - model with two cross cracks
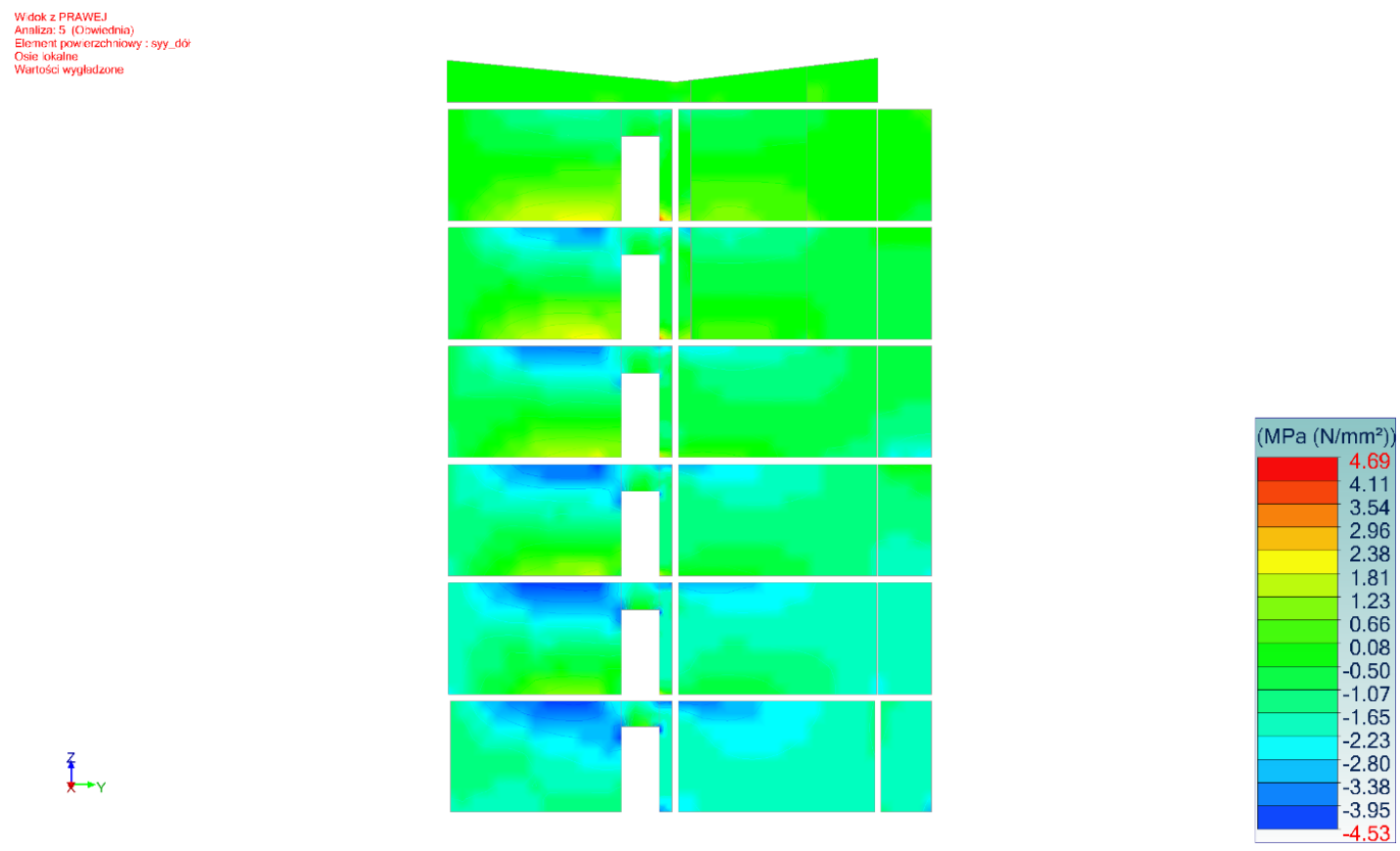

Figure 4. Map of stresses $\sigma_{y y}$ (vertical) in the lower layer - model with 2 cross cracks

The following results were read on the upper warawa (Fig. 6 presents the results from Fig. 5): point $2-2.06$ and 0 , and point $5-3.24$ and 1.62. The points are located in the zone of nodal stresses from the ceilings, which logically influenced the multiplication of the tensile stresses $\sigma[\mathrm{MPa}]$, and thus the stresses $W_{\text {sgn }}[-]$ (designation introduced by the author).

The increase in effort in terms of load capacity for the bottom layer is shown in Fig. 8 (the diagram represents the results in Fig. 7). Originally, the effort was 0 - author's archive. The intensity level did not exceed the value of 1 $[-]$, remaining at the safe level. Particular attention should be paid to the redistribution of stresses and the formation characteristics of secondary normal stress systems $\sigma\left[\mathrm{N} / \mathrm{mm}^{2}\right]$. More about it was written in the author's arguments $[3-7]$. 

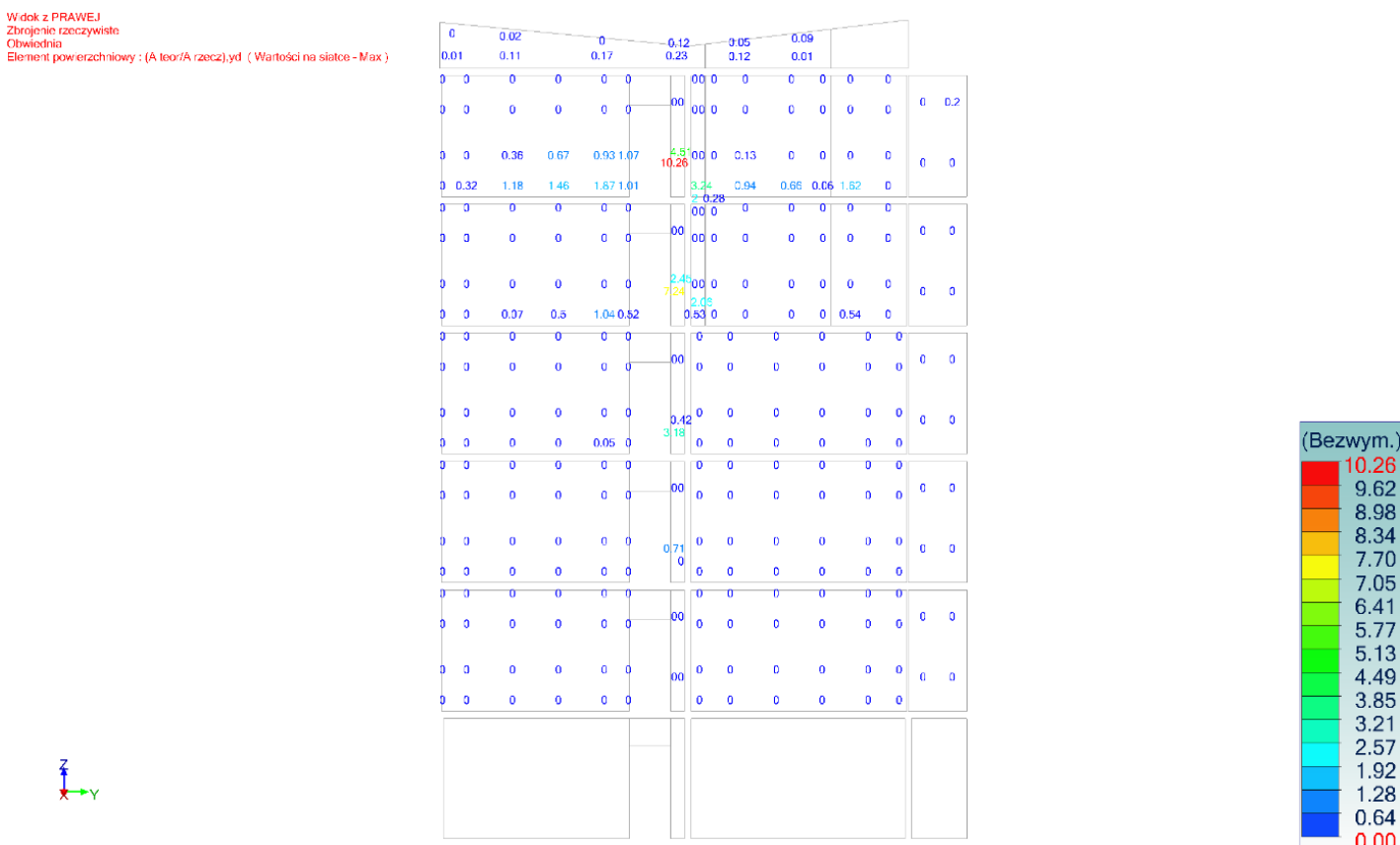

Figure 5. Effort of vertical reinforcement (bottom layer) in ULS

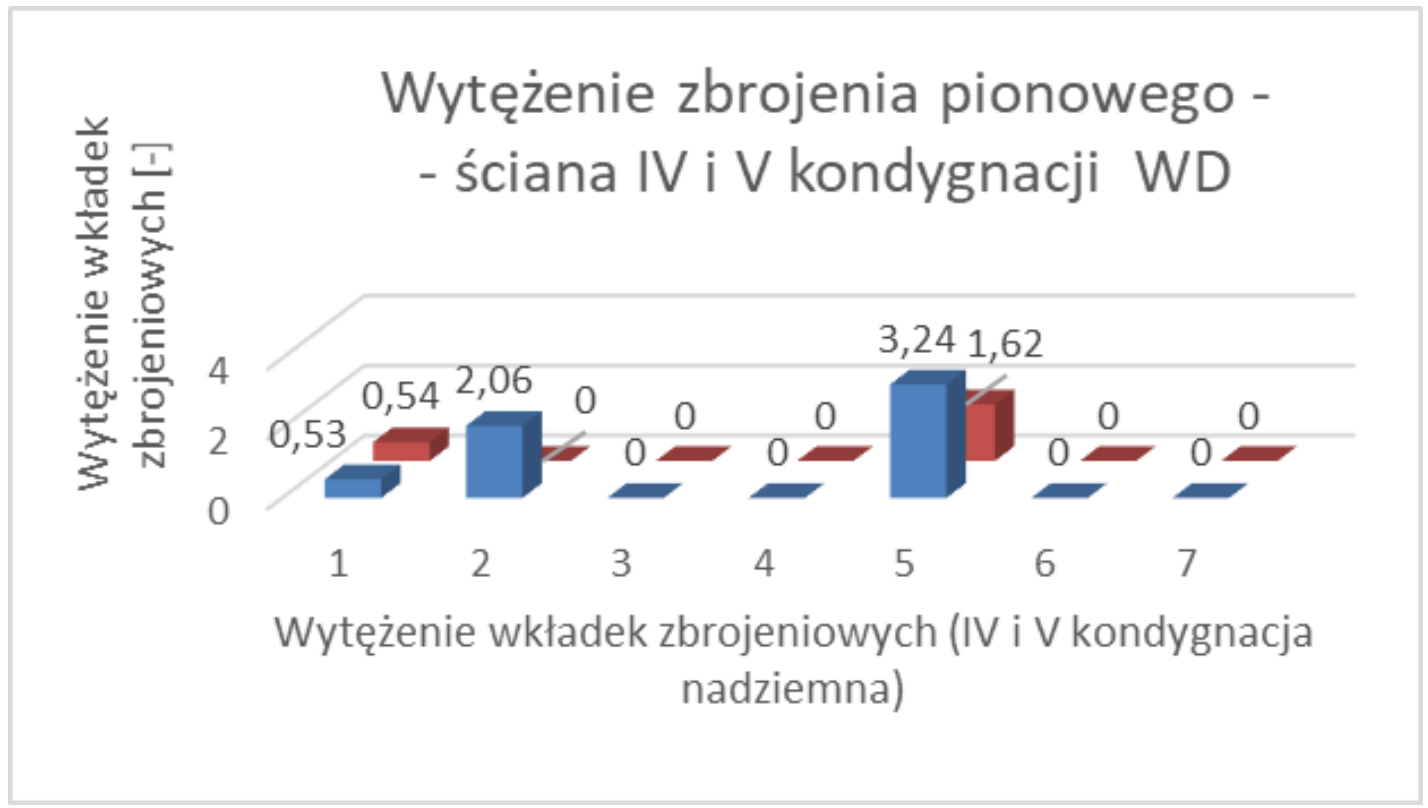

Figure 6. The stress of the vertical reinforcement (bottom layer) in ULS, blue - a crack at a distance of $500 \mathrm{~mm}$ from the axis of the vertical joint; burgundy color $3500 \mathrm{~mm}$

\section{Conclusions}

The reason for the appearance of structural cracks [11] are usually uneven deformations of the soil under the building. Taking into account the use of the structure, the cracks will always be a construction defect. . Surface and local scratches occur mainly in stabilized structures and, without fear of safety, they can be removed during temporary renovation of rooms. Structural cracks, often of a developmental nature, are an obvious indication of a threat to the safety of the structure, this also applies to local features with a propagating morphology. Then the intervention of a construction expert who will define the repair procedure necessary to restore the expected safety condition becomes indispensable. The Dimensionless Limit States Method proposed by the author can be used to measure the safety of all buildings constructed in large slab structural systems. 

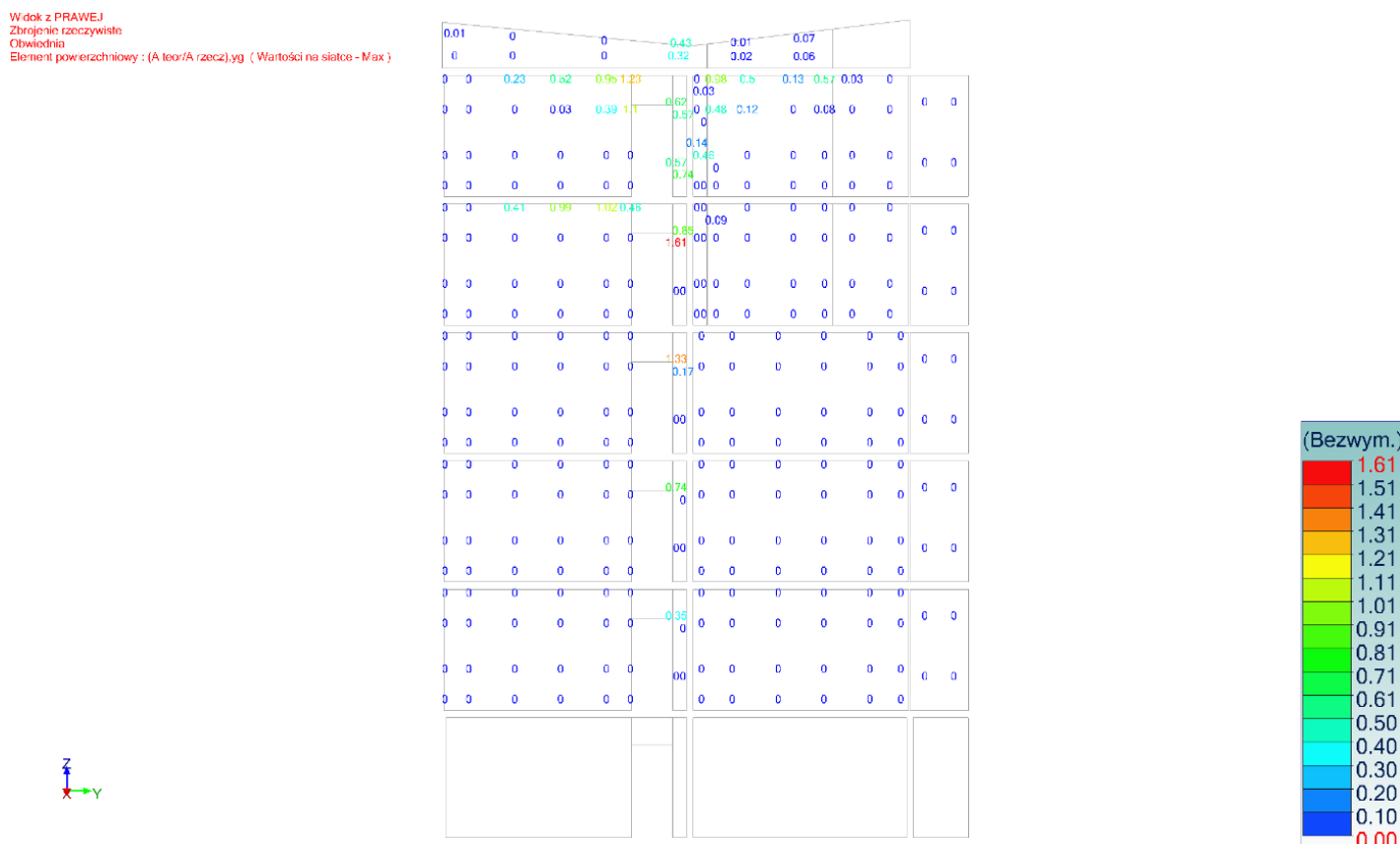

Figure 7. Effort of vertical reinforcement (upper layer) in ULS

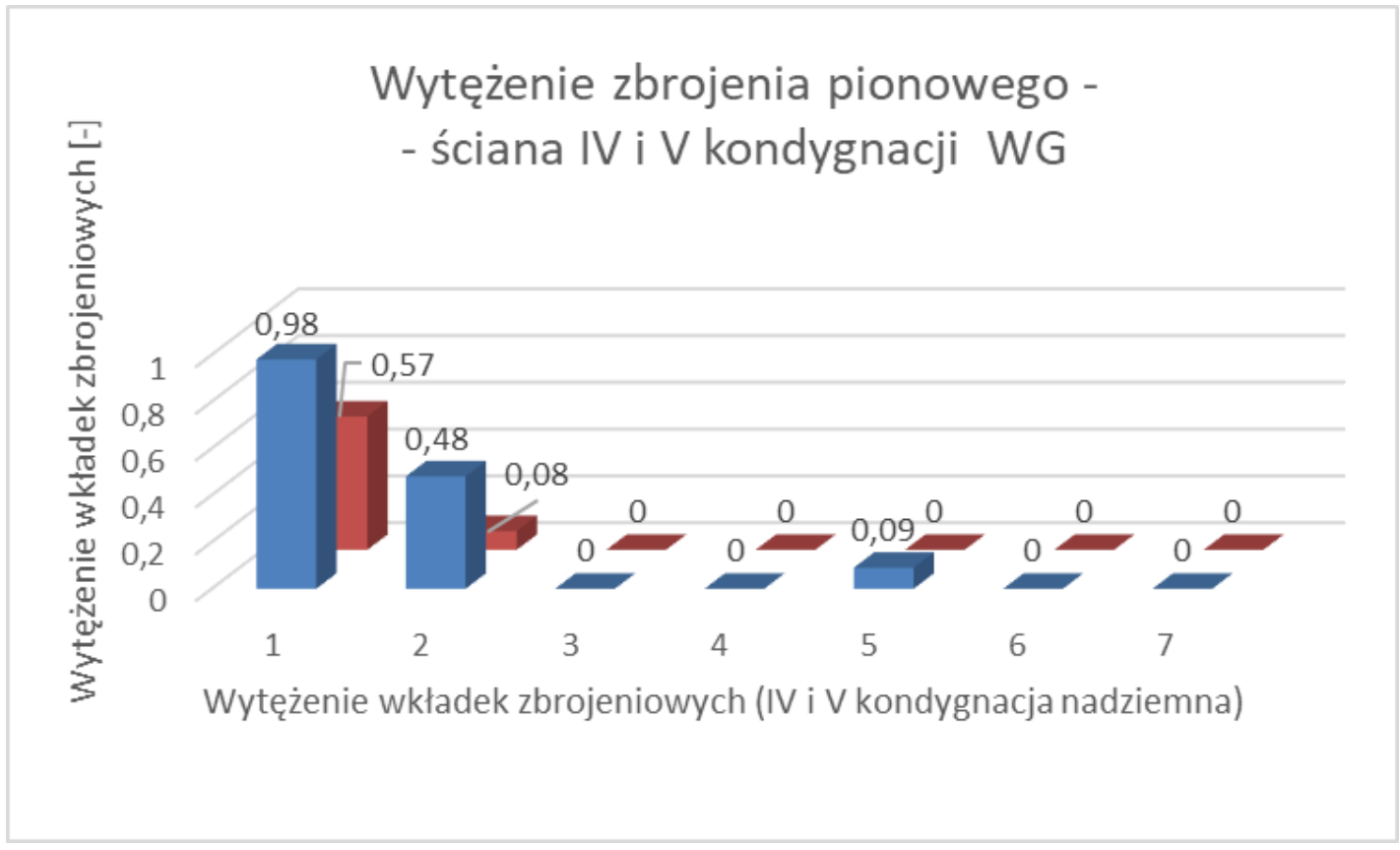

Figure 8. The stress of the vertical reinforcement (upper layer) in ULS, blue - a scratch at a distance of $500 \mathrm{~mm}$ from the axis of the vertical joint; burgundy color $3500 \mathrm{~mm}$

\section{References}

1. Baryłka, A. \& Obolewicz, J. Empiriach veryfication of worksafety evoution. Modern Engineering 3 (2020).

2. Baryłka, A. \& Tomaszewicz, D. Influence of measuring deviations of the components of layered walls on their durability. Inżynieria Bezpieczeństwa Obiektów Antropogenicznych 3. https://doi .org/10.37105/iboa.75 (2020).

3. Bieranowski, P. Author's method of continuum states on the example of imperfection in the construction of a large - panel building. Inżynieria Bezpieczeństwa Obiektów Antropogenicznych, Warszawa, 2 (2020). 
4. Bieranowski, P. Computer security analysis of large panel buildings resulting from the cooperation of the building with the elastic half space of the soil center with the possible scratching of the reinforced concrete composite, Inżynieria Bezpieczeństwa Obiektów Antropogenicznych, 1 (2020).

5. Bieranowski, P. Innowacyjna metodyka szacowania wpływu imperfekcji montażowych na bezpieczeństwo wewnętrznych elementów płytowych w konstrukcjach budynków wielkopłytowych, XXIV Szkoła Komputerowego Wspomagania Projektowania, Wytwarzania i Eksploatacji, Jurata 14-18.09.2020 r. (rozdział w monografii), Komputerowe Wspomaganie Projektowania, Wytwarzania i Eksploatacji, Wojskowa Akademia Techniczna 2020.

6. Bieranowski, P. Komputerowa analiza bezpieczeństwa budynków wielkopłytowych wynikajaca ze wspótpracy budynku z pótprzestrzenią sprężystą ośrodka gruntowego wraz z możliwym zarysowaniem kompozytu żelbetowego, III Konferencja Naukowo-Techniczna, pt. Problemy Inżynierii Bezpieczeństwa Obiektów Antropogenicznych, (rozdział w monografii) Problemy inżynierii bezpieczeństwa obiektów antropogenicznych, Tom II, Centrum Rzeczoznawstwa Budowlanego, Warszawa 2020.

7. Bieranowski, P. Zagadnienia dyskretyzacji w analizie rezultatów na przykładzie modelu powłoki MES dla budynku wielkopłytowego, (rozdział w monografii) Problemy inżynierii bezpieczeństwa obiektów antropogenicznych, Tom II, Centrum Rzeczoznawstwa Budowlanego, Warszawa 2020.

8. Budynki wielkopłytowe - wymagania podstawowe. Zeszyty 1-12. Seria: Instrukcje, wytyczne, poradniki. (ITB).

9. Dzierżewicz, Z. \& Staropolski, W. Systemy budownictwa wielkoptytowego w Polsce w latach 1970-1985. Przeglad rozwiązań materiałowych, technologicznych i konstrukcyjnych. (Wolters Kluwer, Warszawa, 2010).

10. Lewicki, B. Budynki mieszkalne z prefabrykatów wielkowymiarowych (Wydawnictwo Arkady, Warszawa, 1964).

11. Lewicki, B. Rysy w ścianach i stropach budynków wielkopłytowych, Prace ITB nr 2-3 2000.

12. Lewicki B. i, i. Budynki wznoszone metodami uprzemysłowionymi (Arkady, Warszawa, 1979).

13. Ligęza, W. \& Płachecki, M. Analiza uszkodzeń i możliwości wzmacniania konstrukcji budynków wielkopłytowych. in. V konferencja „Warsztat pracy rzeczoznawcy budowlanego" (Kielce, 1999).

14. Lizgęza, W. \& Płachecki, M. Badania efektywności wzmocnienia konstrukcji budynku wielkopłytowego zagrożonego katastrofa in. V konferencja „Warsztat pracy rzeczoznawcy budowlanego" (Kielce, 1999).

15. Runkiewicz L. i, i. Diagnostyka i modernizacja budynków wielkopłytowych, Przegląd Budowlany 7-8/2014 cz. I, 9/2014 cz.II. (2014).

16. Runkiewicz, L. Stosowanie metod nieniszczących do oceny stanu technicznego budynków wielkopłytowych. Przegląd Spawalnictwa 10 (2014). 